\title{
Analysis of Indonesian Capital Market Reaction to the Covid-19
}

\author{
Eka Yulianti ${ }^{1}$, Ifan Wicaksana Siregar ${ }^{1}$ \\ \{eka.yulianti@lecture.unjani.ac.id ${ }^{1}$,ifan.wicaksana.s@lecture.unjani.ac.id ${ }^{2}$ \} \\ Faculty of Economics and Business, Jenderal Achmad Yani University, Indonesia ${ }^{1}$, Faculty of \\ Economics and Business, Jenderal Achmad Yani University, Indonesia ${ }^{2}$
}

\begin{abstract}
This study analyzes the reaction of the Indonesian capital market to the Covid-19 incident by using the Liquid-45 market index (LQ-45). The method used to analyze abnormal returns is the event study method. The research period used is 111 stock exchange days consisting of an estimation period and a window period. The results showed that during the Covid-19 pandemic, the Indonesian capital market was said to be efficient in a half-strong form both in information and decisions. Information efficiency means that the market responds quickly and efficiently in a decision meaning that the market responds appropriately. The negative and significant Average Abnormal Return also reflects the Covid-19 Pandemic has had a negative impact on the Indonesian capital market.
\end{abstract}

Keywords: COVID-19, Event study, Stock Market, Abnormal Return

\section{Introduction}

The capital market is an intermediary that connects parties who are deficient and excess funds. The existence of a capital market can be a solution for companies that lack funds to develop their business by issuing the security. Meanwhile, capital market investors can act as an investment vehicle to channel their funds in the hope of obtaining a return on the investment. However, investing in the capital market does not always mean it is profitable, because various uncertainties can cause losses on the investment. This uncertainty is referred to as investment risk, which is the gap between the expected return and the actual return. This indicates that return and risk are two important aspects that need to be considered in investing in the capital market.

Stock price fluctuations that occur in the capital market are very likely to be influenced by various information regarding certain events. Events that can affect the capital market contain information for investors and may influence investors to buy, sell, and hold shares they own. So that it can affect stock price movements which in turn also affect the return fluctuation. When an investor invests in the capital market, the compensation is returned, but given that returns tend to fluctuate, investors also need to consider the consequences of this investment, namely in terms of taking risks.

Relevant Information to the capital market can be one of the considerations for investors in managing their investments. Along with the development of science and technology, information can easily be spread through various media and absorbed by various parties including investors in the capital market [1]. One of the information that can affect the fluctuation of return is the events that occur in the world, both economic and non-economic, 
although basically the non-economic environment is not directly related to the dynamics of the capital market. Returns in the capital market which tend to fluctuate can be caused by information and should be taken into consideration in investors' decisions to buy or sell shares. The relationship between market reactions to an event is related to the theory of market efficiency. An efficient market is a market where the prices of all securities reflect all available information [2]. In addition, the efficiency of the capital market can also describe a condition in which the prices of securities adjust quickly to new information, and the price reflects all information [3]. Relevant Information to the capital market can serve as an illustration for investors regarding the possible returns and risks that may be borne. If the prices of securities reflect all available information, the market is said to be efficient. In addition, the efficient market is also a market in which the prices of securities adjust quickly to new relevant information.

The Covid-19 disaster is one of the phenomenal events that have occurred in 2020 today. Not only hit Indonesia, the Covid 19 disaster also occurred in various countries around the world. Covid-19 was detected for the first time in early December 2019 and appeared in an animal and seafood market in Wuhan City, China. Covid-19 is a threat to people around the world because of its rapid spread and has caused many fatalities in just two weeks. This pandemic has had a huge impact on economic activity, although the exact extent of the impact is yet unknown. By the end of March 2020, more than 100 countries around the world have implemented lockdown policies [4] Dunford et al. This event is classified as an unexpected event that can become a systematic risk in the context of investment risk. Systematic risk itself is an event that occurs in the market which is not a specific risk that only affects certain companies. Apart from that, this event is also thought to affect capital market activities. This is because these events contain information which can provide negative signals (bad news) for the capital market [5].

On March 2, 2020, for the first time, the government announced two cases of positive Covid-19 patients who infected Indonesian citizens (WNI). The two Indonesian citizens had contact with Japanese citizens who came to Indonesia. In the following days, Covid-19 patients continued to increase until March 9, 2020, for the first time there was a high spike compared to the previous day. On March 8, 2020, there were 8 positive people for Covid-19, and on March 9,2020 , there were 19 people who tested positive [6]. This high case spike for the first time had a negative impact on the capital market where on March 9, 2020, the Jakarta Composite Index (JCI) closed down $6.5 \%$ to 5,136 levels [7]. This incident is a rare occurrence where the JCI can drop so deeply unless it is in serious circumstances like an economic crisis. This situation prompted the capital market regulators and supervisors to take action. On March 10, 2020, the Indonesia Stock Exchange (IDX) announced the implementation of the trading stop or trading halt policy. The policy was taken by IDX by following up on the Order of the Head of the Capital Market Supervision Department 2A of the Financial Services Authority dated March 10,2020 , regarding orders to trade halt trading on the IDX. Under conditions of capital market pressures [8]. The JCI movement before and after the announcement of positive patients for Covid-19 on March 9, 2020, can be seen on the following page: 


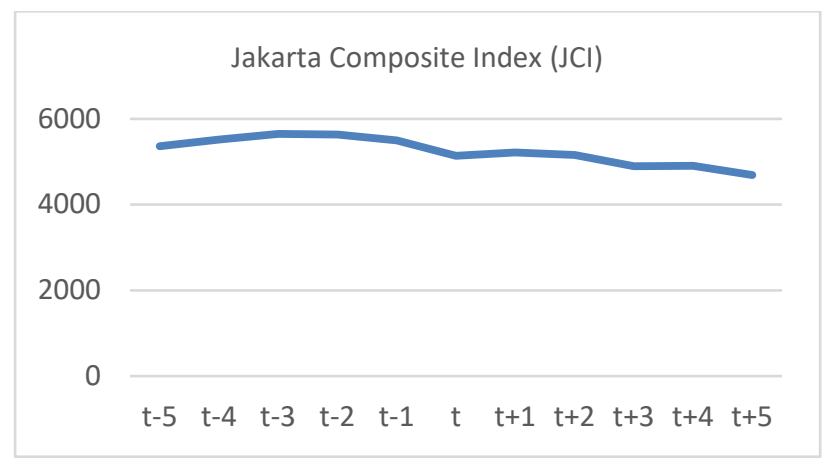

Fig. 1. Development of JCI During The Event Period

Based on the graph above, the JCI decline around the date of the event can be an indicator that the announcement of Covid-19 on March 9, 2020, is considered negative news by investors. Then on March 10, 2020, the IDX carried out halt trading and several other policies so that this was thought to have caused the JCI to increase again. However, because positive cases of Covid19 continued to increase, the JCI movement trend declined again. This is relevant to the movement of one other index in the capital market, namely the LQ-45 index. This index is a stock market index on the IDX which consists of 45 stocks that have high levels of liquidity and market capitalization. So that the shares of the companies listed on this index are the best stocks that have been selected through certain criteria. In addition, the LQ45 index is a stock that is in great demand by investors in the capital market, so it consists of actively traded stocks. In addition, most of the companies that are members of the LQ45 index have supported the JCI movement. The movement of the LQ 45 index before and after the announcement of Covid-19 patients on March 9, 2020, is as follows:

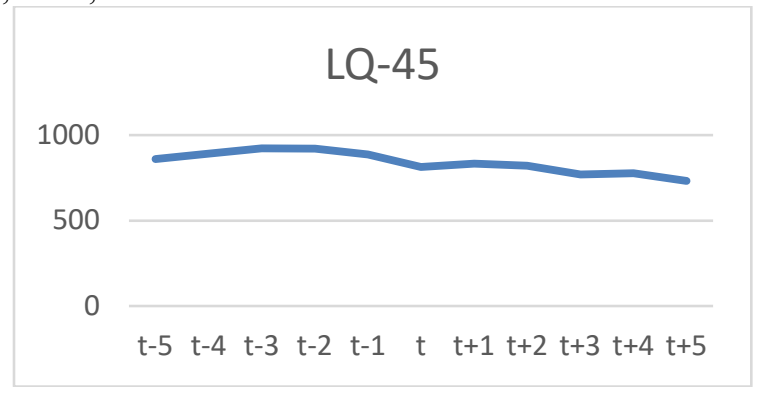

Fig. 2. Development of LQ-45 During The Event Period

Based on the chart above, it can be seen that the movement of the LQ-45 index is relevant to the movement of the JCI. The decline in the value of LQ-45 around the event period was thought to have been caused by the Covid-19 disaster that occurred. Likewise, the JCI the day after the event date, the trend was again increasing. This has become a phenomenon because as stated by Nurmasari [5], the covid-19 news provides a negative signal (bad news) for the capital market. Even so, the increase is thought to be due to policies implemented by the IDX in dealing with the depressed capital market conditions. To ascertain whether this reaction is an effect of Covid-19 and whether the reaction is significant or not, it is necessary to have a more in-depth 
analysis of these events related to testing the efficiency of the capital market. The presence or absence of this reaction can be analyzed using a market efficiency analysis method, namely an event study. An event study is a technique in empirical research in finance that can help researchers to determine the impact or influence of a particular event on stock prices [9]. Measurement of the reaction to an event using an event study can be done by analyzing the abnormal return. If an abnormal return is used, an announcement containing information will give an abnormal return to the market and if it does not contain information, it will not give an abnormal return to the market.

Previous research related to event studies has begun to be carried out in many countries. Research conducted in countries other than Indonesia was conducted by Sansa [10], Alam et al [11], He et al [12], Ashraf [13], Liu et al [14], Khanthavit [15], and Heyden \& Heyden [16]. Meanwhile in Indonesia, the analysis of the capital market reaction to the Covid-19 pandemic and using an event study was conducted by Nurmasari [5]. Nurmasari's research is limited to specific company case studies. Based on the phenomena that have been described and given the limited research on market reactions to the Covid-19 pandemic in Indonesia, the authors would like to try to analyze the reaction of the Indonesian capital market using the LQ-45 market index to this pandemic.

\section{Literature Review}

\subsection{Efficient Market Hypothesis}

The efficient market hypothesis emerged in the 1990s when there was an assumption that the stock market, especially the United States and the United Kingdom, was inefficient. This theory implies that no investor can get above-average profit (abnormal return) [17]. Furthermore, Jones [18]] said that market efficiency shows a condition where the price of securities quickly and fully reflects all relevant information available. An efficient market can be categorized as a market whose share price combines and reflects all available information both past and present [19]. Based on these definitions it can be said that market efficiency is related to how securities prices respond quickly and correctly to available information that can be easily accessed and the information is relevant.

Fama [20] classifies three main forms of market efficiency based on the type of information used. The first is the weak form of market efficiency which assumes the market is said to be efficient if the prices of securities do not fully reflect past information. This past information is information that has happened. The weak form of market efficiency is related to the random walk theory which assumes that past data are not related to present values. If the market is efficient in a weak form, then past values cannot be used to predict current prices. This means that in this form of market efficiency, investors cannot use past information to gain an abnormal profit. Second, the semi-strong form of market efficiency, which assumes the market is said to be efficient in the half-strong form if securities prices fully reflect all published information (all publicly available information). The purpose of published information is information that is publicly available so that it is easily accessible by capital market players. Third, a strong form of market efficiency assumes that the market is efficient when securities prices fully reflect all available information including private information. If the market is efficient in this form, then no individual or individual investor can get an abnormal return because they have private information. Furthermore, in 1991, Fama perfected the three forms of market efficiency, including the weak form efficiency into a form to test the predictability of 
returns. The efficiency of the semi-strong form is transformed into an event study and testing of market efficiency in the strong form is known as private information testing.

\subsection{Event Study}

Event study or event study is a method that can be used to measure the impact of an event on securities prices. In addition, Jogiyanto [21] suggests an event study can be said to be a way of research to measure the effect of a specific event using financial data on the value of a company. This event study can also be used to test the content of information, Mackinlay [22]. This information content can be in the form of good information and bad information. Fama [20] revealed the market is said to be efficient in the form of a half strong if the stock price quickly fully reflects the newly available and relevant information. This means there are two main elements that are the main characteristics of an efficient capital market, namely the availability of relevant information and prices adjusting quickly to new information.

The reaction to the information in the event study method is measured by the abnormal return which is the difference between the actual return and the expected return. The steps that can be taken in conducting an event study, in general, are as follows, Tandelilin [2]:

1. Determine events or events of interest

2. Determining the event window (window period), in this study the estimation period is also determined. The estimation period (T-n-e to T-n) is the period used to forecast the expected return in the event period. The estimation period is required if the calculation of abnormal returns uses statistical models and economic models. Meanwhile, if the calculation of abnormal returns uses a model adjusted to the market, there is no need for an estimation period.

3. Select a sample of companies to be analyzed

4. Elimination of annoying events that can reduce the accuracy of the analysis

5. Determine the abnormal return

This abnormal return is the difference between the actual return and the expected return (normal return). The formula that can be used to calculate abnormal returns is as follows:

$$
\mathrm{AR}_{\mathrm{it}}=\mathrm{R}_{\mathrm{it}}-\mathrm{E}\left(\mathrm{R}_{\mathrm{it}} \mid \mathrm{X}_{\mathrm{t}}\right)
$$

Furthermore, in this study the expected return is calculated using the Mean Adjusted Model with the following formula:

$$
E\left(R_{i t}\right)=\frac{\sum_{t=-n-e}^{t=-n} R_{i t}}{T}
$$

1. Determining Average Abnormal Return (AAR) and Cumulative Average Abnormal Return (CAAR)

2. Testing the significance of abnormal return to see whether there is a significant reaction around the event. If there is a significant abnormal return, it means that there is a reaction from the analyzed events on stocks and vice versa.

Previous research on individual studies that measure the reaction of the capital market to a disaster has been widely carried out. Some research related to the Covid-19 disaster was conducted by Sansa [10]. Sansa [10] conducted research related to the effects of the Covid-19 pandemic on capital markets in China and the USA. The index used as a sample from China is the Shanghai Stock Exchange (SSE) and the New York Dow Jones (NYDJ) as samples from the USA. This study uses a simple regression technique where the Covid-19 case is the 
independent variable while SSE and NYDJ are the dependent variables. The results of their research show that the Covid-19 Pandemic had a significant impact on the capital markets of China and the USA in the period March 1, 2020, to March 25, 2020. Furthermore, Alam et al[11]] conducted research on the reaction of the Indian capital market to the announcement of the lockdown policy caused by the Covid-19 pandemic. The research technique used is an event study that analyzes 31 companies that are members of the Bombay Stock Exchange (BSE) index. The results showed investors reacted positively to the implementation of the lockdown policy as evidenced by the significant positive abnormal returns around the lockdown announcement. In line with Sansa [10], He et al [12] conducted research on the reaction of the capital market in various industrial sectors in China to the Covid 19 pandemic. The results of their research show that the transportation, mining, electricity \& heating, and environmental sectors have been affected by the pandemic. Meanwhile, the manufacturing, information technology, education, and health care industries can survive the pandemic. Furthermore, Ashraf [13] conducted a more extensive study, namely analyzing the reaction of the capital market to the COVID-19 pandemic by using daily positive cases and deaths due to confirmed Covid-19 data and stock return data from 64 countries around the world. The period used is from January 22, 2020, to April 17, 2020. The results show the stock market has responded negatively to the growth in confirmed cases of COVID-19. That is, stock market returns decrease as the number of confirmed cases increases. In addition, the results also show that the stock market reacts more proactively to growth in the number of confirmed cases compared to growth in the number of deaths. The results of this study, if generalized, show that the stock market is rapidly responding to the COVID-19 pandemic and this response varies over time depending on the extent of the pandemic's spread. Then, Liu et al [14] conducted a study on the short-term impact of the coronavirus outbreak on 21 leading stocks that are included in market indexes in the main affected countries including Japan, Korea, Singapore, the US, Germany, Italy, and the UK, etc. This research using the event study method shows that the main countries and regions affected by the Covid-19 stock market experienced a rapid decline after the pandemic hit. Abnormal returns in negative countries are greater than in other countries. This means that the capital market reacted negatively to the Covid-19 pandemic. Khantavhit [15] also conducted an event study analysis to test the stock market's reaction to COVID-19. The research was carried out on the capital markets of France, Germany, Italy, Spain, UK, USA, China, the Philippines, and Thailand. This study shows there is a significant negative reaction to the disease. Furthermore, Heyden \& Heyden [16] research analyzes the short-term market reaction of US and European stocks during the COVID-19 pandemic. The research was conducted using an event study. The results showed that the market reacted negatively to the Covid-19 pandemic case that occurred. In addition, the research results also show that several policies implemented by the government during the pandemic have a negative effect on returns.

In Indonesia, research on the reaction of the capital market to the Covid-19 pandemic was conducted by Nurmasari [5]. This study uses the event study method but only analyzes one company, namely PT. Ramayana Lestari Sentosa, Tbk). The event date used was the announcement of Covid-19 patients on March 2, 2020. The results showed there was a significant difference in stock prices before and after the announcement of the first Covid-19 case in Indonesia. Where the stock price has decreased compared to before the Covid-19 case. Meanwhile, the volume of stock transactions also shows a significant difference.

\section{Research Methods}


This research uses a quantitative research approach with a descriptive analysis method. The descriptive analysis method is used because this study aims to determine whether or not the Indonesian capital market has reacted to the Covid-19 incident. In addition, the method used to analyze abnormal returns is the event study method. The research period used was 111 stock exchange days consisting of an estimation period and a window period. The estimation period used in this study is 100 days, namely t- 6 to t-105 before the event date. Furthermore, the window period is determined as 11 days, namely 5 days before the event, 1 day of the event date, and 5 days after the announcement of Covid 19 on March 9, 2020.

The population in this study is all stocks included in the LQ-45 index on the Indonesia Stock Exchange. Furthermore, the sampling technique is a saturated sample because the entire population is used as the sample. The author uses documents, namely the closing price data for the stock index i on day $\mathrm{t}$, and the JCI. This method is also supported by data collection from internet media to achieve the research objectives.

\section{Results And Discussion}

\subsection{Discussion (One-Sample T-Test Results Against the Calculation of Average Abnormal Return (AAR)}

The purpose of this study was to determine the reaction of the capital market to the Covid19 announcement on March 9, 2020. This reaction can be measured by conducting the OneSample T-test on the variables studied on the observation days. In this study, the One-Sample T-test was carried out on the Average Abnormal Return (AAR) variable which was first tested for data normality as follows:

Table 1. Normality Test Results

\begin{tabular}{llccc}
\hline & & \multicolumn{3}{c}{ TESTING } \\
NO & VARIABLE & P: value & $\begin{array}{c}\text { Level } \\
\text { Significan }\end{array}$ & eXPLANATION \\
& & & $\boldsymbol{c e}$ & \\
\hline 1 & AAR before & 0.053 & 0.05 & Normal \\
2 & AAR after & 0.150 & 0.05 & Normal \\
\hline
\end{tabular}

Source: Data Processing Results, 2020

Based on the SPSS output in the table above, the results of the Kolmogorov Smirnov test on the AAR variable both before and after the event were normally distributed. This can be seen from the P: value before AAR is 0.053 and $\mathrm{P}$ : after value is 0.153 which is greater than 0.05 . The results of the One-Sample T-Test can be seen on the following page:

Table 2. The Results of the One-Sample T-Test AAR 


\begin{tabular}{ccccc}
\hline WINDOW & AVERAGE & \multicolumn{3}{c}{ TESTING } \\
\cline { 3 - 5 } PERIOD & ABNORMAL & p- & $\mathbf{0 , 0 5}$ & Explanation \\
& RETURN & Value & & \\
\hline t-5 & (AAR) & & & \\
t-4 & 0,7739 & 0,000 & 0,05 & Significant \\
t-3 & 0,7946 & 0,000 & 0,05 & Significant \\
t-2 & $-0,2170$ & 0,035 & 0,05 & Significant \\
t-1 & $-0,8241$ & 0,001 & 0,05 & Significant \\
t0 & $-0,1777$ & 0,000 & 0,05 & Significant \\
t+1 & $-0,3740$ & 0,001 & 0,05 & Significant \\
t+2 & $-0,5829$ & 0,001 & 0,05 & Significant \\
t+3 & $-0,1205$ & 0,000 & 0,05 & Significant \\
t+4 & $-0,0259$ & 0,797 & 0,05 & Not Significant \\
t+5 & $-0,0239$ & 0,000 & 0,05 & Significant \\
\hline S0uryyyy & $-0,1400$ & 0,000 & 0,05 & Significant \\
\hline
\end{tabular}

Source: Data processing results, 2020

Based on Table 2, the announcement of Covid-19 patients that occurred on March 9, 2020, there were 2 positive AARs, 9 negative AARs, and most of them were significant. As said by Sansa [10], Alam et al [11]], He et al [12], Ashraf [13]], Liu et all [14], Khanthavit [15], and Heyden \& Heyden [16] that pandemic events Covid-19 is negative news which causes the market index to fall and results in the negative abnormal return value. The existence of AAR is positive at t-5 and t- 4 and it is significant the market has not responded to the Covid-19 pandemic because before t-0 Covid-19 patients in Indonesia were still confirmed to be under five cases except for $t-1$ which had six cases.

Furthermore, at $t-3$ to $t+5$ cases, positive patients with Covid-19 increased so that it caused AAR to be negative and almost entirely significant except at $t+3$. This means the stock market reacted negatively to this pandemic event. In addition, the event date and the period approaching the event date such as $\mathrm{t}-1, \mathrm{t}-2, \mathrm{t}+1, \mathrm{t}+2$, and $\mathrm{t}+3$ are all negative and significant. This reflects the market is information efficient because it responds quickly and is also efficient in terms of decisions because this negative news is also responded negatively by the market. This decisionbased market efficiency statement is also supported by the theory put forward by Tandelilin [2] which states that market efficiency by a decision can be seen from the negative or positive sign of the abnormal return value.

Furthermore, the insignificant AAR value is probably due to the implementation of capital market policies by the financial services authority to overcome stressed capital market conditions such as trading halt. So that this policy can at least reduce the impact of the pandemic on the capital market. The results of this study are relevant to the research of Nurmasari [5], Sansa [10], Alam et al [11], He et al [12], Ashraf [13], Liu et al [14], Khanthavit [15], and Heyden \& Heyden [16] who showed the results that the Covid-19 pandemic had a negative impact on the capital market, both on the Indonesian capital market, and in various other countries in the world. 


\section{Conclusions and Suggestions}

Based on the results and discussion previously described, it can be concluded that during the Covid-19 pandemic the market was said to be efficient in a half-strong form both in information and decisions. Information efficiency means that the market responds quickly and efficiently in a decision meaning that the market responds appropriately because negative news is responded negatively by the market. A negative and significant AAR also reflects that the Covid-19 Pandemic has had a negative impact on the Indonesian capital market.

Based on the conclusions in the previous sub-chapter, the suggestions that can be given are as follows: investors should reconsider their investment strategies in a pandemic situation such as the Covid-19 pandemic. Periodic portfolio reviews are required in line with the initial investment objectives. The decline in the stock market provides many opportunities for investors to start building portfolios. Buying, if done properly with sufficient knowledge, will have the opportunity to provide benefits. Although there are still concerns, historically there are several sectors that tend to be defensive, such as the consumer and health sectors.

Currently, there are many other options for investing in addition to capital market instruments such as stocks, bonds, and mutual funds. Investment diversification can be through alternative investments widely offered by fintech platforms such as Equity Crowdfunding (ECF), Project Financing, and Peer-to-Peer (P2P). investors need to allocate more emergency funds to stay awake at a certain time. Emergency funds can be held directly by cash or allocated in savings, time deposits, or money market mutual funds.

For further research, the researcher should increase the observation period to see the extent of the effect given from news related to health problems and also should be able to use a compounding effect.

\section{References}

[1] E. Yulianti and D. Jayanti, "Penerapan Model Garch Untuk Menguji Efisiensi Pasar Bentuk Lemah | Yulianti | Sains: Jurnal Manajemen dan Bisnis," Sains J. Manaj. dan Bisnis, vol. 12, 2020.

[2] E. Tandelilin, Analisis Investasi dan Manajemen Portofolio, 1st ed. Yogyakarta: BPFE, 2017.

[3] K. C. Brown and R. F. K, Analysis of Investments and Managements Portofolios, Ninth. south western, Texas indiana: Cengage Learning, 2008.

[4] D. Dunford, B. Dale, and I. T. Stylianou, Nassos, Ed, Lowther, Ahmed, M., Arenas, "Coronavirus: the World in Lockdown in Maps and Charts," 2020.

[5] I. Nurmasari, "Dampak Covid - 19 Terhadap Perubahan Harga Saham dan Volume Transaksi (Studi Kasus Pada PT. Ramayana Lestari Sentosa, Tbk.),” J. Sekuritas, vol. 3, no. 1, pp. 230-236, 2020.

[6] A. Bayu, "Rekap Kasus Virus Corona di Indonesia, sejak 2 Maret hingga 7 April 2020 - Halaman 2 - Tribunnews.com," Tribun News, Apr-2020.

[7] D. Sugianto, "Perjalanan IHSG Sejak RI Positif Virus Corona," detikFinance News, Apr-2020.

[8] BEI, "PT Bursa Efek Indonesia (BEI) Terapkan Ketentuan mengenai Trading Halt atas Perdagangan di Bursa," BEI press release, 2020. .

[9] Z. K. Bodie and A. Maarcus, Investments: Investasi., Internatio. Jakarta: Salemba Empat, 2008.

[10] N. A. Sansa, "The Impact of the COVID-19 on the Financial Markets: Evidence from China and USA," SSRN Electron. J., no. April, 2020.

[11] M. N. Alam, M. S. Alam, and K. Chavali, "Stock market response during COVID-19 lockdown period in India: An event study," J. Asian Financ. Econ. Bus., vol. 7, no. 7, pp. 131-137, 2020. 
[12] P. He, Y. Sun, Y. Zhang, and T. Li, "COVID-19's Impact on Stock Prices Across Different Sectors-An Event Study Based on the Chinese Stock Market," Emerg. Mark. Financ. Trade, vol. 56, no. 10, pp. 2198-2212, 2020.

[13] B. N. Ashraf, "Since January 2020 Elsevier has created a COVID-19 resource centre with free information in English and Mandarin on the novel coronavirus COVID- 19 . The COVID-19 resource centre is hosted on Elsevier Connect , the company 's public news and information ," no. January, 2020.

[14] H. Liu, A. Manzoor, C. Wang, L. Zhang, and Z. Manzoor, "The COVID-19 outbreak and affected countries stock markets response," Int. J. Environ. Res. Public Health, vol. 17, no. 8, pp. 1-19, 2020.

[15] A. Khanthavit, "World and National Stock Market Reactions to COVID-19," no. 2019, pp. 1-17, 2020 .

[16] K. J. Heyden and T. Heyden, "Market Reactions to the Arrival and Containment of COVID-19: An Event Study," SSRN Electron. J., no. April, 2020.

[17] A. . Khan and S. Ikram, "Testing Semi-Strong Form of Efficient Market Hypothesis in Relation to the Impact of Foreign Institutional Investors' (FII's) Investments on Indian Capital Market," Int. J. Trade, Econ. Financ., vol. Vol.1, No., 2010.

[18] C. P. Jones, Investments, 10 edition. New York, 2007.

[19] A. Timmermann and C. W. J. Granger, "Efficient market hypothesis and forecasting," Int. J. Forecast., vol. 20, no. 1, pp. 15-27, 2004.

[20] E. Fama, "Efficient Capital Markets: A Review Of Theory And Empirical Work.," J. Financ. 25 383-417, 1970.

[21] H. Jogiyanto, Teori Portofolio dan Analisis Investasi, Enam. Yogyakarta: BPFE, 2010. 